\title{
Investing in the Energy Future
}

An Industry Guide to Licensing Technologies at the National Renewable Energy Laboratory
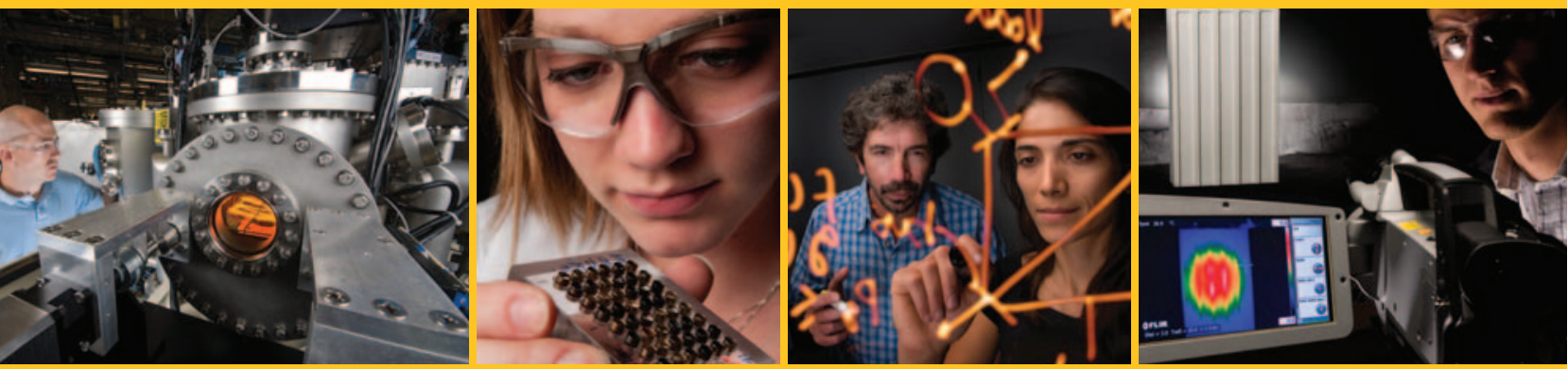

NREL is a national laboratory of the U.S. Department of Energy, Office of Energy Efficiency and Renewable Energy, operated by the Alliance for Sustainable Energy, LLC. 


\section{NREL and You}

Transforming the energy future requires a broad portfolio of technologies. Through its advancement of renewable energy and energy efficiency technologies, the U.S. Department of Energy's (DOE's) National Renewable Energy Laboratory (NREL) is a leading force in this transformation. NREL bridges the gap between basic and applied research to translate discoveries into energy innovations with potential to become market-viable solutions.

We invite you to explore the commercialization potential of NREL's innovations. You'll find opportunities to license a multitude of next-generation energy technologies. You can invest in the energy future.

\section{NREL's R\&D Competencies}

- Renewable electricity conversion and delivery systems

- Renewable fuels formulation and delivery

- Efficient and integrated energy systems

- Strategic energy analysis 


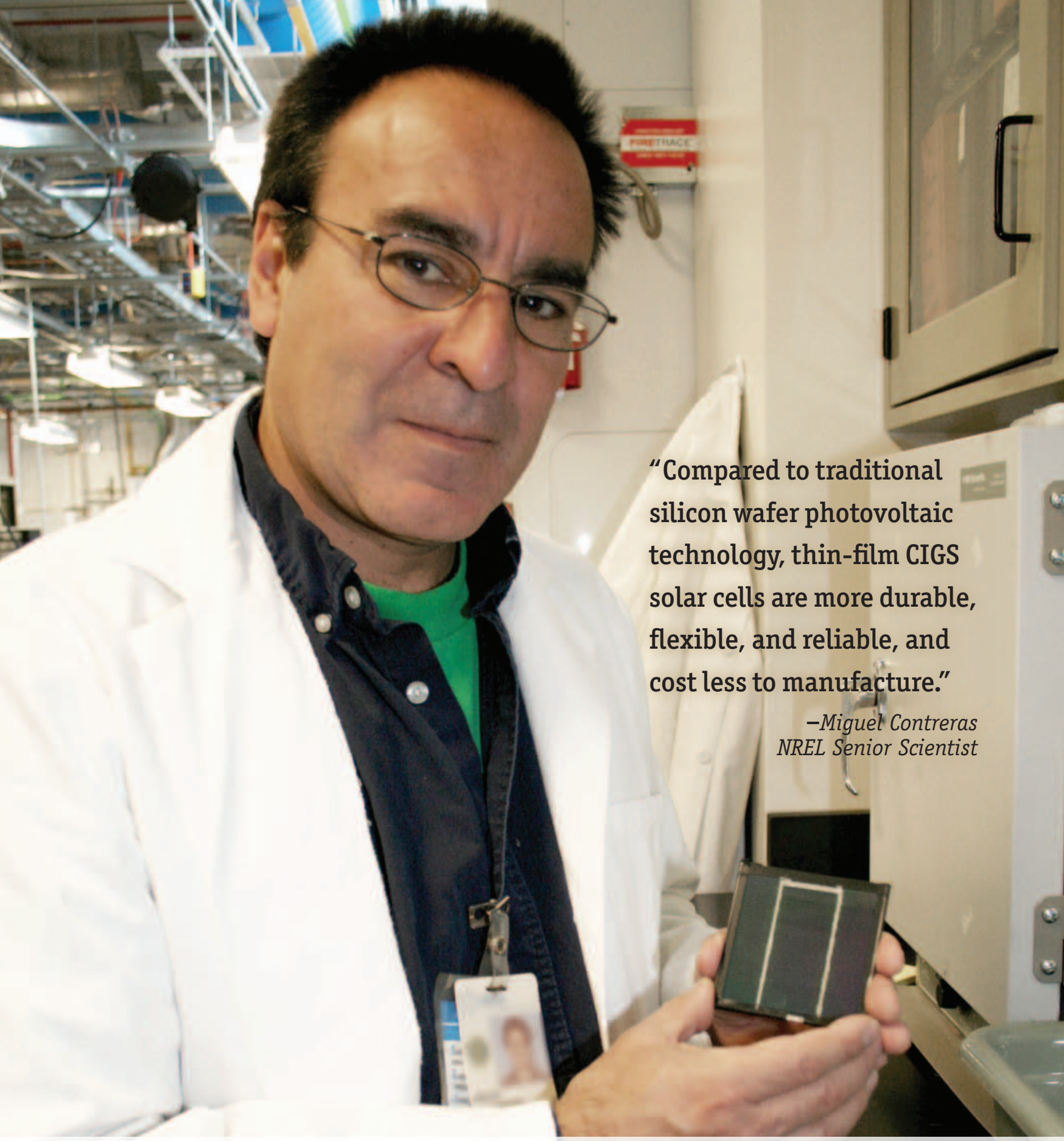

NREL Senior Scientist Contreras holds one of the copper indium gallium diselenide (CIGS) thin-film solar cells he invented. These solar cells have an energy conversion efficiency that's just as high as polycrystalline silicon solar cells. Credit: Ray David, NREL 


\section{Our Innovations}

NREL researchers invent cutting-edge technologies with an innovative eye towards market-relevant, sustainable energy applications. We have hundreds of technologies available for licensing within the laboratory's R\&D program areas:

- Advanced vehicles and fuels

- Basic sciences

- Biomass

- Buildings

- Concentrating solar power

- Electric infrastructure systems
- Energy analysis

- Geothermal

- Hydrogen and fuel cells

- Photovoltaics

- Wind 


\section{Working with Us}

At NREL, we focus on accelerating the commercialization of our energy innovations. This means we work to quickly complete business transactions with companies interested in licensing our technologies.

If your company is interested in licensing an NREL technology, one of our experienced licensing executives will guide you through our process, which includes four basic steps.

\section{Step 1. Protecting Proprietary Information}

To help your company make a decision about licensing an invention, NREL may need to share proprietary information with you. To do so, we need to ensure that the information is protected from public disclosure. It may involve developing a nondisclosure agreement.

\section{Step 2. Evaluating the}

\section{Licensing Opportunity}

When evaluating an opportunity, an NREL licensing executive will look at the scope and nature of the desired license agreement and help determine the necessary level of exclusivity, geographic scope, and field of use among other details. You'll also be asked to submit a brief commercialization strategy outlining the product, the market, expected launch date, and expected sales within the first five years.

\section{Step 3. Drafting and Negotiating} License Agreement

If you elect to enter into a license agreement, an NREL licensing executive will work with you to create a term sheet. This term sheet will help to document the understanding between both parties on the primary financial and nonfinancial terms and conditions. The terms will then be incorporated into one of NREL's agreement templates.

The licensing executive will provide you with the draft license agreement for review by your legal counsel.

\section{Step 4. Post-Execution}

Once the license has been executed, the NREL licensing executive will stay in touch with you to keep track of your progress commercializing the technology and to help you resolve any unforeseen problems. The licensing executive will also be your primary point of contact for any questions about royalty payments. 


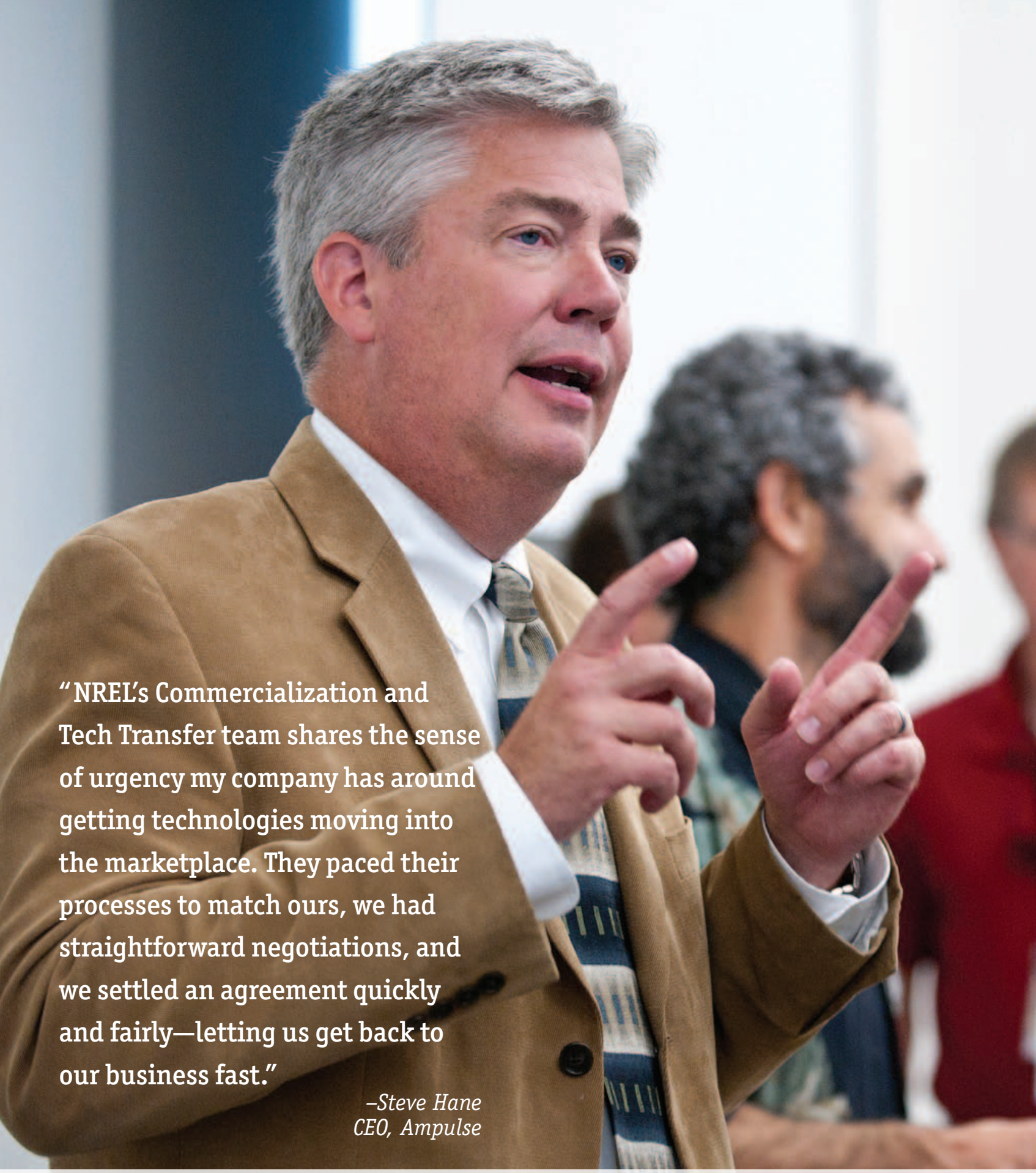

Ampulse CEO Steve Hane is working closely with NREL to develop inexpensive silicon solar cells using a process his company has licensed from NREL. Credit: Dennis Schroeder, NREL
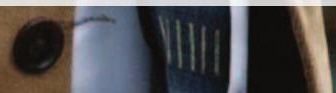


\section{In Your Own Words}

Here's what some of you say about your experiences working with and licensing technologies from NREL.

"I believe NREL is an example of how a government-funded entity should be run... In my opinion, any company and particularly startup companies in renewable energy MUST partner with NREL and to do anything else will not be the best suitable entrepreneurial approach."

"Working with NREL was smooth and professional every step of the way."

“The technology portfolio Planar Energy spun-out of NREL promises to revolutionize the energy storage industry by making large format ceramic batteries practical and cost effective. NREL has proven to be a powerful and flexible partner for Planar in bringing together the right talent, technology and leadership to build the next generation of high-performance energy storage solutions."

“Through partnership and license agreements with NREL, we've been able to streamline the technology transfer and accelerate the development of the world record efficiency cadmium telluride thin-film PV technology developed at the lab. We're now ready for commercial product introduction, and much of our success can be attributed to the early help and support that we've had from NREL."

"The staff at NREL were very helpful and also very patient with our questions and deliberations,"

"As a small business, we devote our resources carefully and move swiftly. We've been very pleased with the response and timeliness of NREL's Technology Transfer Office, as well as their willingness to respond to issues that come up as we grow and expand." 
“The Technology Commercialization \& Deployment Fund helped us advance ReflecTech Mirror Film, a technology used in our SkyTrough collector."

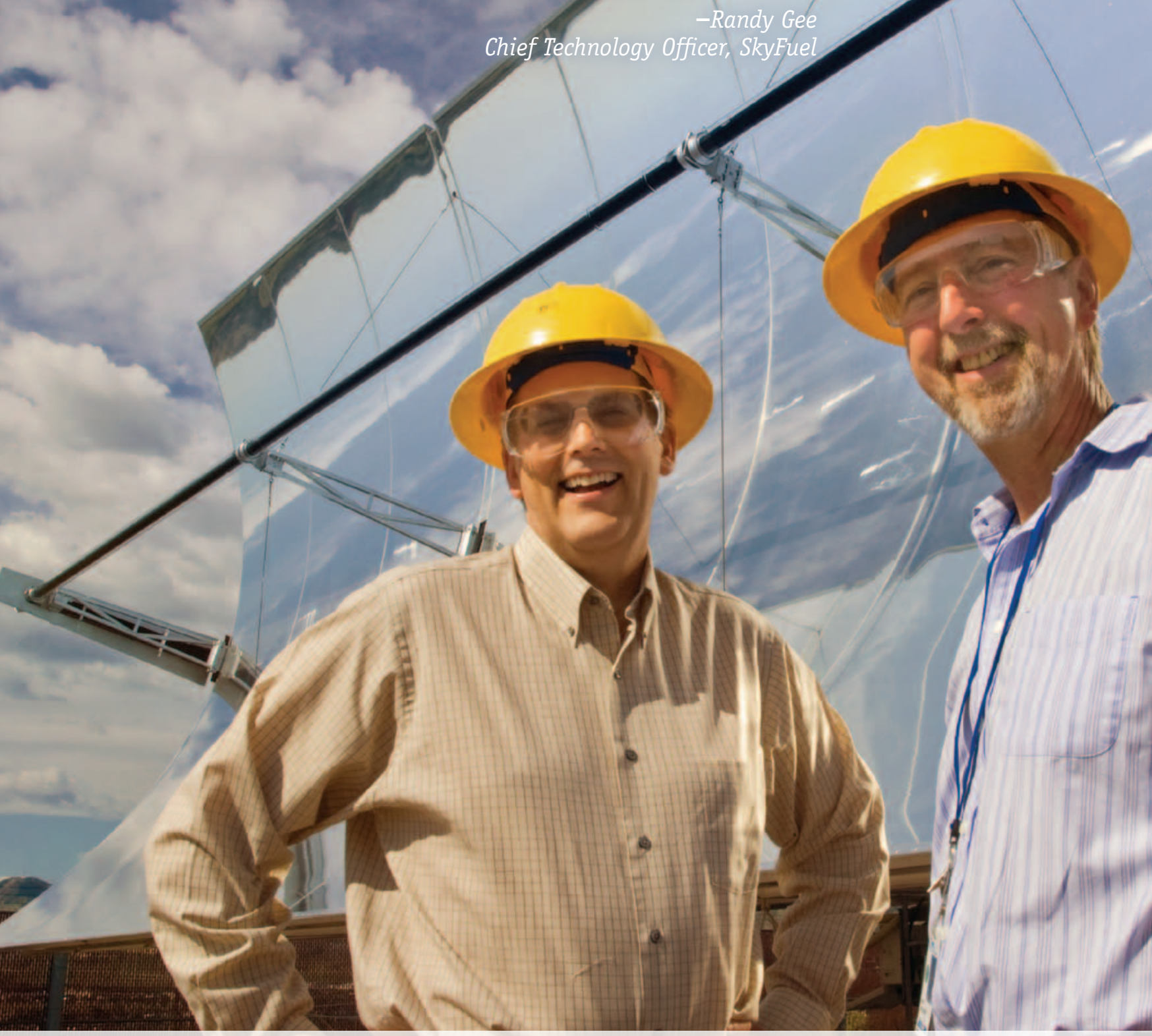

From DOE's Technology Commercialization \& Deployment Fund, NREL received \$4 million to invest in company partnerships developing promising new technologies, like the thin mirror film for parabolic troughs invented by SkyFuel Chief Technology Officer Randy Gee (left) and NREL Principal Scientist Gary Jorgensen (right). Credit: Pat Corkery, NREL

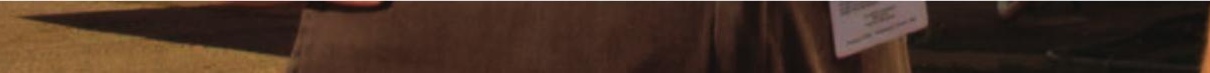




\section{Our Commercialization Programs}

Through our commercialization programs, we help investors and companies find licensing opportunities, accelerate the transfer of technologies into the marketplace, and stimulate the formation of clean energy startup companies.

\section{Commercialization Assistance Program}

The NREL Commercialization Assistance Program (NCAP) helps emerging companies overcome technical barriers to commercializing clean energy technology. The program specifically helps renewable energy and energy efficiency companies by providing free assistance or information to help small businesses with specific technology questions or needs. Learn more about NCAP at www. nrel.gov/technologytransfer.

\section{Industry Growth Forum}

For over 15 years, NREL's Industry Growth Forums have provided clean energy entrepreneurs an opportunity to present their business cases to an expert panel of investors and energy executives. Since 2003, presenting companies have raised nearly $\$ 3.4$ billion in growth financing. Learn more about the Forum at www.cleanenergyforum.com.

\section{Privately Funded Technology Transfer Program}

To leverage the federal government's investment, the Alliance for Sustainable Energy, which operates NREL, has introduced a privately funded technology transfer program. Under the program, the Alliance partners will invest $\$ 1.75$ million to fund basic patenting, marketing, and licensing activities. NREL will also use the funds to attract external investments, primarily for innovations developed under DOE programs.

\section{Technology Commercialization Portal}

NREL developed and manages the Technology Commercialization Portal for the DOE Office of Energy Efficiency and Renewable Energy. The Web site provides streamlined searching and browsing of patents, patent applications, and marketing summaries for clean energy technologies available for licensing from DOE laboratories and participating research institutions. Visit the Technology Commercialization Portal at techportal.eere.energy.gov. 

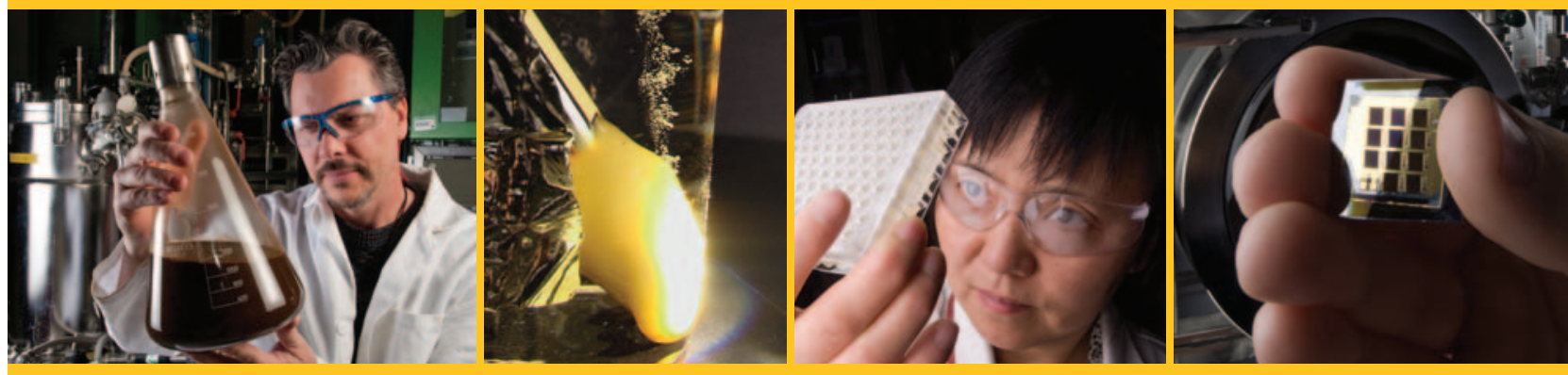

National Renewable Energy Laboratory

15013 Denver West Parkway, Golden, C0 80401 303-275-3000 • www.nrel.gov

NREL is a national laboratory of the U.S. Department of Energy

Office of Energy Efficiency and Renewable Energy

Operated by the Alliance for Sustainable Energy, LLC

\section{NREL/BR-7A1-48108 • September 2010}

Printed with a renewable-source ink on paper containing at least $50 \%$ wastepaper, including $10 \%$ post consumer waste. 